\title{
Fish Diversity and Fish Assemblage Structure in Seagrass Meadows at Sikao Bay, Trang Province, Thailand
}

\author{
Wikit Phinrub ${ }^{1,2 *}$, Bunyat Montien-Art ${ }^{1}$, Jongkol Promya ${ }^{1}$, Apinun Suvarnaraksha1 \\ ${ }^{1}$ Faculty of Fisheries Technology and Aquatic Resources, Maejo University, Chiang Mai, Thailand \\ ${ }^{2}$ Faculty of Science and Fisheries Technology, Rajamangala University of Technology, Srivijaya, Thailand \\ Email: "wkit_ph@hotmail.com
}

Received 25 November 2015; accepted 18 December 2015; published 21 December 2015

Copyright (C) 2015 by authors and Scientific Research Publishing Inc.

This work is licensed under the Creative Commons Attribution International License (CC BY). http://creativecommons.org/licenses/by/4.0/

(c) (i) Open Access

\begin{abstract}
We investigated the relationship between environmental variables as descriptors of the fish community, in terms of species diversity indices and fish assemblage patterns, in seagrass meadows at Sikao Bay, Trang Province, Thailand. Fish data and water quality parameters were collected from January to December 2012. A total of 10,596 fish specimens of 97 taxa in 48 families from four stations, Kham Bay $\left(7^{\circ} 30^{\prime} 9.21^{\prime \prime} \mathrm{N}, 9^{\circ} 18^{\prime} 7.67^{\prime \prime} \mathrm{E}\right)$, Boonkong Bay $\left(7^{\circ} 31^{\prime} 2.49^{\prime} \mathrm{N}, 9^{\circ} 17^{\prime} 40.09^{\prime \prime} \mathrm{E}\right)$, Ban Pak Klong ( $7^{\circ} 36^{\prime} 17.67^{\prime \prime} N, 9^{\circ} 16^{\prime} 32.89^{\prime \prime}$ ) and Sai Cape $\left(7^{\circ} 38^{\prime} 30.19^{\prime \prime} N, 99^{\circ} 14^{\prime} 49.85^{\prime \prime E}\right)$, were collected using gillnets of three different mesh sizes. The three most diverse families were Leiognathidae, Carangidae and Tetraodontidae, respectively. The dominant species were Atherinomorus duodecimalis, Sillago sihama and Pelates quadrilineatus. Specimens were highly abundant in July and less so in January and species richness was high in July and less so in March. Fish assemblages were classified into two patterns and the average of the Shannon index was 2.7. The environmental parameters in each month were analyzed by one-way ANOVA which did not show significant difference $(P>0.05)$ of $\mathrm{pH}$, orthophosphate, wind speed and rainfall. Fish diversity and assemblage, and environmental parameters, were categorized into four groups. These could be promoted to local fisheries so that conservation programs cpuld be set up to ensure the ecological sustainability of seagrass meadows.
\end{abstract}

\section{Keywords}

Fish, Diversity, Canonical Correspondence Analysis, Seagrass, Sikao Bay

\footnotetext{
${ }^{*}$ Corresponding author.
}

How to cite this paper: Phinrub, W., Montien-Art, B., Promya, J. and Suvarnaraksha, A. (2015) Fish Diversity and Fish Assemblage Structure in Seagrass Meadows at Sikao Bay, Trang Province, Thailand. Open Journal of Ecology, 5, 563-573. 


\section{Introduction}

Seagrass meadows are considered a valuable component of coastal ecosystems, as they are an important habitat for numerous fish, invertebrates and other animals, perform different ecological functions and act as environmental reserves. They supply a permanent habitat to fulfil the life cycles of aquatic animals, especially as a temporary nursery area for juvenile stages [1] [2], and as feeding areas for all life stages [3] [4]. Seagrass meadows also provide benefits to humans in terms of protein source security, as well as occupation for coastal populations [5] [6]. Seagrass beds have high primary productivity; the habitat provides suitable protective cover for many species of marine fish and invertebrates and is an important tropical marine [7]. Variations in environmental variables are the major factors that govern marine fish communities in terms of species richness and distribution of individual species. They are important in terms of fish biology and ecology and related studies of life history and population dynamics. Understanding these relationships is tremendously important to support fisheries management, economics, social aspects and environmental protection. Seagrass meadows in particular are very sensitive ecosystems with a huge diversity of species and related assemblage patterns. In Thailand, huge seagrass meadows of 12 species extending to 18,986 hectares (ha) can be found. The biggest seagrass meadows in Thailand are located in Trang Province (3,435 ha) with 11 species, where Sikao Bay has 350 ha of seagrass meadows. However, fish diversity and assemblage in the seagrass meadows of Sikao Bay have not been studied thoroughly, and environmental factors in particular have not been considered recently. Our study examines fish diversity and assemblages, and relationships between species richness and environmental parameters. The results can be used in the future as a basis for comparison with other seagrass meadows in South East Asia and other tropical marine systems. They also support aquatic resources conservation strategies, which should be prepared in the near future to protect this sensitive seagrass meadow ecosystem.

\section{Materials and Methods}

\subsection{Study Area Description}

The study area was located in Sikao Bay (Kham Bay, $7^{\circ} 30^{\prime} 9.21^{\prime \prime N}$, 99¹8'7.67"E; Boonkong Bay, 7³1'2.49"N,

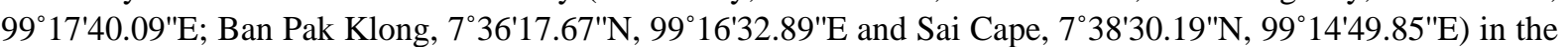
Andaman Sea, Trang Province, Southern Thailand. Sikao Bay is $126 \mathrm{~km}^{2}$ in area with a shore length of $40 \mathrm{~km}$. The most frequent seagrass species in this area are Enhalus acoroides, Cymodocea rotundata, Thalassia hemprichii, Halophila ovalis, Halophila minor and Halodule pinifolia.

\subsection{Fish Sampling}

Fish sampling was carried out during the night at four sites on Sikao Bay from January to December 2012. Fishing was done with three experimental gillnets of different mesh sizes (2, 3.5 and $5 \mathrm{~cm}$ ), 180-m long and 1.5 $\mathrm{m}$ deep, connected into one net for fish sampling. Specimens were fixed in $10 \%$ formalin for 1 month and then changed to ethanol 30\%, 50\% for a month. Finally, they were preserved in $70 \%$ ethanol and re-checked and identified taxonomically to species level level [8]-[12] at the Maejo Aquatic Resources Natural Museum (MARNM), Faculty of Fisheries Technology and Aquatic Resources, Maejo University, Chiangmai, Thailand.

\subsection{Environmental Parameter Sampling}

The physico-chemical water quality parameters measured in situ using a YSI ${ }^{\circledR} 556$ multi-Probe System (MPS) made in the USA were conductivity (Con), total dissolved solid (Tds), salinity (Sal), dissolved oxygen (Dis), pH $(\mathrm{pH})$, water temperature (Tem) and transparency (Tra). Other parameters were sampled for laboratory analyses using the standard methods: ammonia (Amm), nitrite (Nti), nitrate (Nta), orthophosphate (Ort) and chlorophyll $a$ (Chla) [13]. Data were collected in Sikao Bay at the four fish sampling sites on a monthly basis from January to December 2012. Meteorological parameters data were maximum air temperature (Mat), minimum air temperature (Mit), average air temperature (Aat), wind direction (Wid), wind speed (Wis) and rainfall (Rai). These data were provided by the Thai Meteorological Department [14]. The highest water level (Hwa) and lowest water level (Lwa) were provided by the Hydrographic Department, Royal Thai Navy [15]. 


\subsection{Data Analyses}

The physico-chemical water quality parameters, meteorological parameters, fish species (Fsp) and fish numbers (Fnu) were analyzed using Pearson rank correlation tests and one-way ANOVA (Tukey honestly significant difference test, $P=0.05$ ) conducted with the SPSS $^{\odot}$ software package. The data set is presented as the percentage of occurrence frequency (\% OF), species richness and Shannon diversity index [16], to examine the relationships between species richness and environmental parameters using Canonical Correspondence Analysis (CCA) and Principal Component Analysis (PCA), an ordination technique designed for direct analysis of relationships between multivariate ecological data [17]. All statistical analyses were performed using R-statistical software, packages "stats" [18] [19].

\section{Results}

\subsection{Fish Diversity}

A total of 10,596 fish specimens of 97 taxa in 48 families was collected (Table 1). Leiognathidae was the most abundant with eight species (15\%) (Leiognathus stercorarius, L. jonesi, L. decorus, L. equulus, L. fasciatus, $L$. splendens, Secutor insidiator and Gazza minuta). This was followed by seven species (13\%) of Carangidae (Alepes kleinii, Carangoides praeustus, Megalaspis cordyla, Scomberoides lysan, Siganus commersonnianus, Decapterus kurroides and Caranx sexfasciatus) and seven species (13\%) of Tetraodontidae (Tetraodon fluviatilis, T. palembangensis, T. nigroviridis, Lagocephalus spadiceus, L. lunaris, Chelonodon patoca and Arothron reticularis) (Figure 1). The dominant species were Atherinomorus duodecimalis, Sillago sihama and Pelates quadrilineatus. The highest frequencies of occurrence were S. sihama (79.17\%), Atherinomorus duodecimalis (72.92\%) and Hyporhamphus limbatus (68.75\%), respectively (Figure 2). Specimens were highly abundant in

Table 1. Fish species found in the seagrass medowsin Sikao Bay, Trang Province, Thailand.

\begin{tabular}{|c|c|c|c|c|c|}
\hline Family & Scientific name & Abb & Family & Scientific name & Abb \\
\hline Dasyatidae & Himantura imbricata & Himb & & Secutor insidiator & Sins \\
\hline Megalopidae & Megalops cyprinoides & Мсур & & Gazza minuta & Gmir \\
\hline \multirow[t]{4}{*}{ Engraulidae } & Thryssa hamiltonii & Tham & Lutjanidae & Lutjanus russelli & Lrus \\
\hline & Stolephorus indicus & Sind & & Lutjanus fulviflamma & Lful \\
\hline & Thryssa setiorostris & Tset & Lobotidae & Lobotes surinamensis & Lsur \\
\hline & Thryssa scratchleyi & Tscr & Gerreidae & Gerres erythrourus & Gery \\
\hline \multirow[t]{2}{*}{ Clupeidae } & Sardinella albella & Salb & & Gerres oyena & Goye \\
\hline & Anodontostoma chacunda & Acha & & Gerres filamenttosus & Gfil \\
\hline Plotosidae & Plotosus lineatus & Plin & Haemulidae & Plectorhinchus gibbosus & Pgib \\
\hline Bagridae & Mystus gulio & Mgul & & Pomadasys kaakan & Pkaa \\
\hline Synodontidae & Saurida nebulosi & Sneb & Lethrinidae & Lethrinus lentjan & Llen \\
\hline \multirow[t]{4}{*}{ Mugilidae } & Chelon subviridis & Csub & Sciaenidae & Pennahia anea & Pane \\
\hline & Ellochelon vaigiensis & Evai & Mullidae & Upeneus tragula & Utra \\
\hline & Moolgarda cunnesius & Mcun & & Parupeneus heptacanthus & Phep \\
\hline & Valamugil perusii & Vper & Toxotidae & Toxotes chatareus & Tcha \\
\hline Atherinidae & Atherinomorus duodecimalis & Aduo & Drepanidae & Drepane punctate & Dpun \\
\hline Hemiramphidae & Hyporhamphus limbatus & Hlim & Teraponidae & Pelates quadrilineatus & Pqua \\
\hline
\end{tabular}




\section{Continued}

\begin{tabular}{|c|c|c|c|c|c|}
\hline & Zenarchopterus buffonis & Zbuf & & Terapon puta & Tput \\
\hline \multirow[t]{2}{*}{ Belonidae } & Tylosurus crocodiles crocodilus & Tcro & & Terapon jarbua & Tjar \\
\hline & Strongylura strongylura & Sstr & Labridae & Halichoeres bicolor & Hbic \\
\hline Syngnathidae & Syngnathoides biaculeatus & Sbia & Blenniidae & Petroscirtes variabilis & Pvar \\
\hline Scorpaenidae & Vespiculatrachinoides & Vtra & Callionymidae & Repoтисепus schaapii & Rsch \\
\hline Synanceiidae & Synanceia horrida & Shor & Eleotridae & Butis butis & Bbut \\
\hline \multirow[t]{4}{*}{ Platycephalidae } & Grammoplites scaber & Gsca & Gobiidae & Oxyurichthys microlepis & Omic \\
\hline & Platycephalus indicus & Pind & & Acentrogobius caninus & Acan \\
\hline & Cociella punctata & Cpun & & Yongeichthys nebulosus & Yneb \\
\hline & Inegonia japonica & Ijap & & Psammogobius biocellatus & Pbio \\
\hline \multirow[t]{4}{*}{ Ambassidae } & Ambassis nalua & Anal & Scatophagidae & Scatophagus argus & Sarg \\
\hline & Ambassis vachellii & Avac & Siganidae & Siganuscanaliculatus & Scan \\
\hline & Ambassis urotaensis & Auro & & Siganus javus & Sjav \\
\hline & Ambassis interruptus & Aint & & Siganus fuscescens & Sfus \\
\hline Latidae & Lates calcarifer & Lcal & Sphyraenidae & Sphyraena barracuda & Sbar \\
\hline Apogonidae & Apogon truncates & Atru & Scombridae & Rastrelliger brachysoma & Rbra \\
\hline \multirow[t]{2}{*}{ Sillaginidae } & Sillago sihama & Ssih & Paralichthyidae & Pseudorhombus arsius & Pars \\
\hline & Sillago aeolus & Saeo & Soleidae & Zebrias quagga & Zqua \\
\hline Rachycentridae & Rachycentron canadum & Rcan & Cynoglossidae & Cynoglossus puncticeps & Cpuc \\
\hline \multirow[t]{7}{*}{ Carangidae } & Alepes kleinii & Akle & & Cynoglossus abbreviatus & Cabb \\
\hline & Carangoides praeustus & Cpra & Triacanthidae & Triacanthus nieuhofii & Tnie \\
\hline & Megalaspis cordyla & Mcor & Monacanthidae & Monacanthus chinensis & Mchi \\
\hline & Scomberoides lysan & Slys & Ostraciidae & Lactoria cornuta & Lcor \\
\hline & $\begin{array}{l}\text { Scomberomorus } \\
\text { commersonnianus }\end{array}$ & Scom & Tetraodontidae & Tetraodon fluviatilis & Tflu \\
\hline & Decapterus kurroides & Dkur & & Tetraodon palembangensis & Tpal \\
\hline & Caranx sexfasciatus & Csex & & Tetraodon nigroviridis & Tnig \\
\hline \multirow[t]{6}{*}{ Leiognathidae } & Leiognathus stercorarius & Lste & & Lagocephalus spadiceus & Lspa \\
\hline & Leiognathus jonesi & Ljon & & Lagocephalus lunaris & Llun \\
\hline & Leiognathus decorus & Ldec & & Chelonodon patoca & Cpat \\
\hline & Leiognathus equulus & Lequ & & Arothron reticularis & Aret \\
\hline & Leiognathus fasciatus & Lfas & Diodontidae & Diodon liturosus & Dlit \\
\hline & Leiognathus splendens & Lspl & & & \\
\hline
\end{tabular}

Abb. = Abbreviation. 


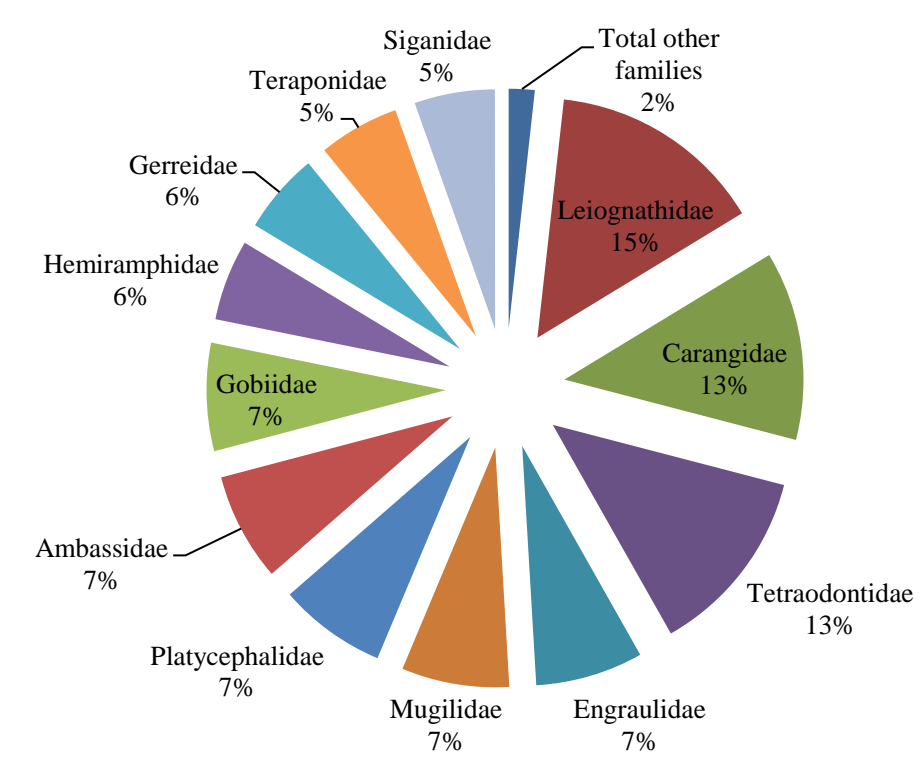

Figure 1. Percentage dominat families of fishes in seagrass areas at Sikao Bay, Trang Provice, Thailand.
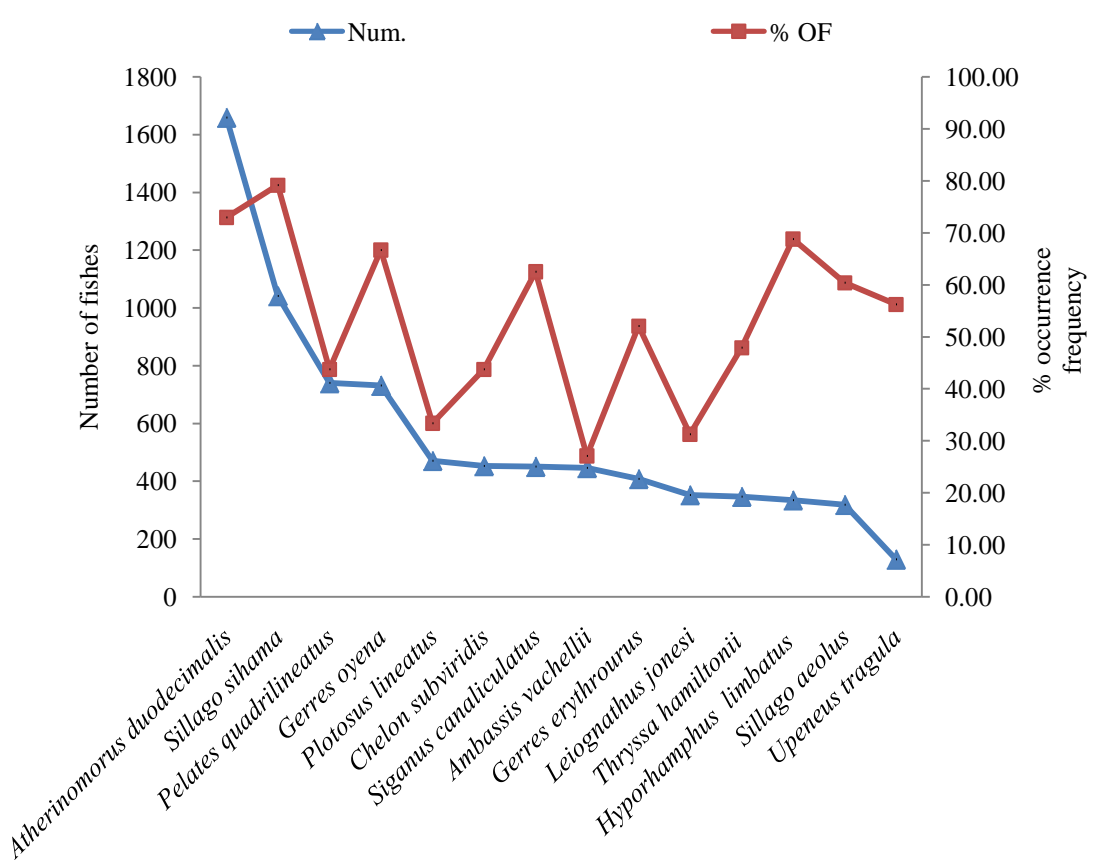

Figure 2. Number of dominant species and percentage of occurrence frequence of fishes in seagrass areas at Sikao Bay, Trang Province, Thailand.

July and less so in January (Figure 3(a)), and species richness was high in July and lain March, (Figure 3(b)). The average Shannon-Wiener index was 2.7.

\subsection{Environmental Parameters}

The 20 environmental parameters, fish species and fish numbers were analyzed by Pearson rank correlation tests. The results showed significance of conductivity, ammonia, fish numbers, fish species and highest water level $(P$ $<0.05$ ). The results analyzed by one-way ANOVA, the environmental parameters measured in each month did not show significant difference $(P>0.05$ ) of $\mathrm{pH}$, orthophosphate (Ort), wind speed (Wis) and rainfall (Rai). 
Four seagrass meadows and environmental parameters showed no significant relationships $(P>0.05)$. The environmental parameters measured in dry seasons and rainy seasons showed a significant difference $(P<0.05)$ of water temperature (Tem), wind direction (Wid), lowest water level (Lwa) and highest water level (Hwa).

\subsection{Prediction of Species Richness and Environmental Parameters}

Ninety-seven fish species and 20 environmental variables from four sampling sites were log-transformed and fed to a CART model as a response variable to be predicted using fish species and environmental variables. The major factor in physico-chemical and meteorological parameters was Chlorophyll $a$. The CART model using the tree "pruning" process and optimal tree selection favored three parameters including Chlorophyll $a$ (Chl), lowest water level (Lwa) and total dissolved solid (Tds). Chlorophyll $a$ was used in both the first and the second splits. This model showed that if chlorophyll $a$ levels were higher than $0.5 \mu \mathrm{g} / \mathrm{l}$, species diversity was high with about 26 species (Figure 4).

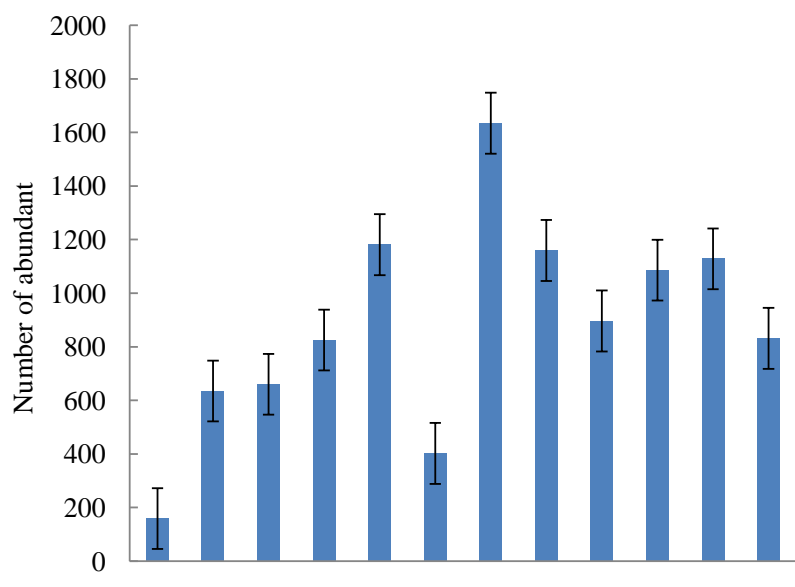

Jan Feb Mar Apr May Jun Jul Aug Sep Oct Nov Dec

(a)

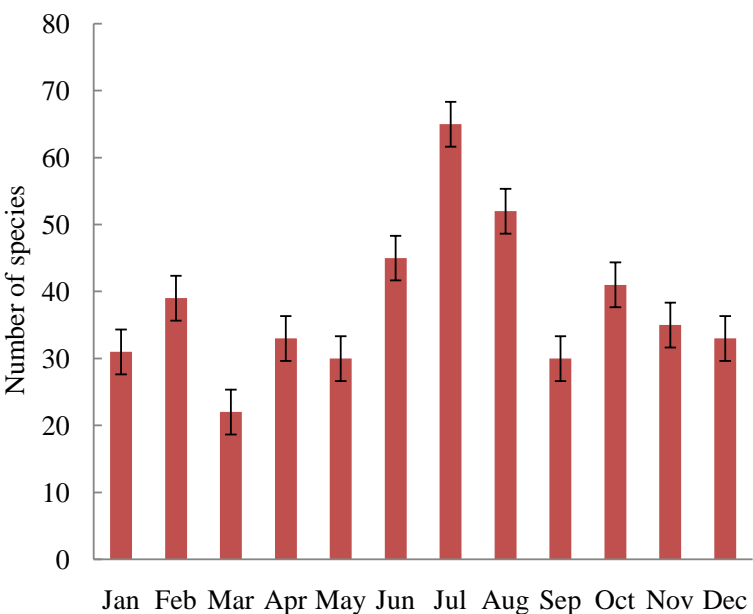

(b)

Figure 3. The abundant species (a) and species richness (b) of fishes in seagrass meadowns at Sikao Bay, Trang Province, Thailand.

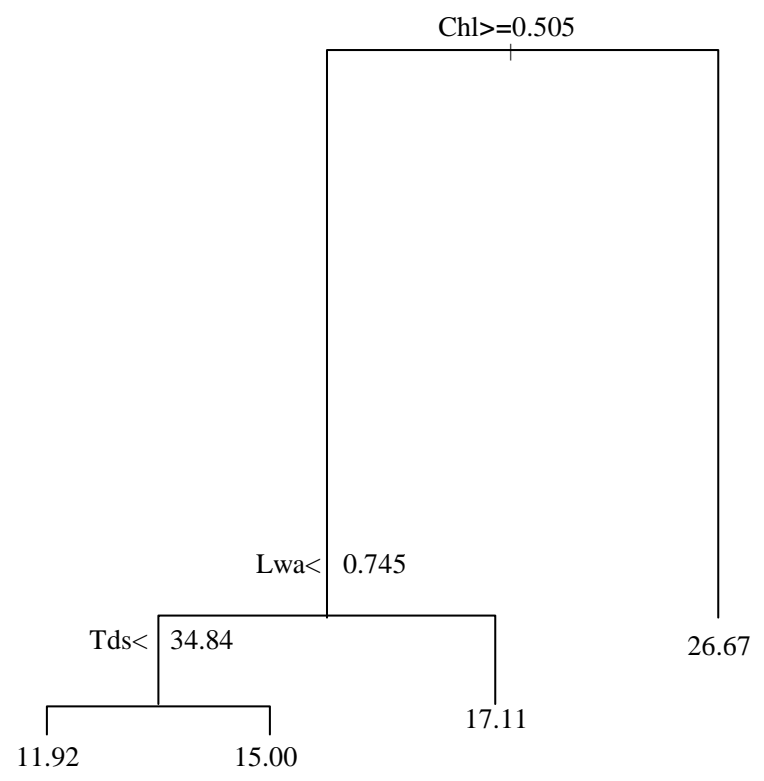

Figure 4. CART model to predict species richness in seagrass meadowns at Sikao Bay, Trang Province, Thailand. 


\subsection{Relationships of Fish Assemblage Structure and Environmental Parameters}

Ninety-seven fish species and 20 environmental variables were analyzed by CCA, including common fish species such as S. sihama (Ssih), A. duodecimalis (Aduo), H. limbatus (Hlim), Gerres oyena (Goye), P. quadrilineatus (Pqua), S. aeolus (Saeo), Upeneus tragula (Utra) and G. erythrourus (Gery) which can be classified into four groups (Figure 5(a), Figure 5(b)).

The first group (I) represented species including Rastrelliger brachysoma (Rbra), Cynoglossus puncticeps (Cpuc) and Lutjanus russelli (Lrus), related to rainfall (Rai) and nitrite (Nti). In group II were found most dominant species such as S. sihama (Ssih) and Siganus janus (Sjan), and Triacanthus nieuhofi (Tnie), related to highest water levels (Hwa) and wind direction (Wid). Group III represented species such as Sig. canaliculatus (Scan), Cynoglossus abbreviatus (Cabb) and Monacanthus chinensis (Mchi), related to average air temperature (Aat), maximum air temperature (Mat) and conductivity (Con). Finally, Group IV included species such as Thryssa scratchleyi (Tscr), Cociella punctata (Cpun) and Petroscirtes variabilis (Pvar), related to salinity (Sal) and total dissolved solid (Tds).

The results are shown in a cluster dendrogram, summarizing the similarity of species richness with environmental parameters (plotted by CCA), including the cluster composition of species at the sampling site through all the year (Figure 5(c)), which can be classified into two main groups. The first group (A) represents the similarity of species richness related to the environmental variables in the dry season (January, February, March and April), the beginning of the rainy season (May and June) and in the central part and end of the rainy season (September, October, November and December). The dominant fish species were A. duodecimalis (Aduo), G. oyena (Goye), Sillago aeolus (Saeo)and Siganus canaliculatus (Scan), (January, February, March and April); H. limbatus (Hlim), Sillago sihama (Ssih), and G. oyena (Goye) (May and June); and S. sihama (Ssih), H. limbatus (Hlim), A. duodecimalis (Aduo) and Siganus canaliculatus (Scan), (September, October, November and December). The second group (B) represents similarity of species richness related to the environmental variables in the rainy season (July and August) with dominant species as Sillago sihama (Ssih), S. aeolus (Saeo), A. duodecimalis (Aduo), G. erythrourus (Gery), Pennahia anea (Pane), Drepane punctate (Dpun), Leiognathus jonesi (Ljon), Platycephalus indicus (Pind), Ambassis nalua (Anal), Thryssa hamiltonii (Tham) and Chelon subviridis (Csub).

Further results then appear in a cluster dendrogram, summarizing the similarity of species in terms of environmental parameters (plotted by CCA) and showing the composition at the sampling site throughout the year (Figure 5(d)), which can also be classified into two main groups. The first group (A) represents the similarity in environmental variables at the end of the dry season (March and April) and at the beginning and central part of the rainy season (May, June, July, August and September). The second group (B) represents the similarity in environmental variables at the end of the rainy season (October, November and December) and at the beginning of the dry season (January and February).

\section{Discussion}

In this study, we found fish diversity in seagrass meadows in Sikao Bay, Trang Province, Thailand, was 97 taxa in 48 families relative with seagrass meadows, which is similar to the findings, [20] who found 81 fish species and to [21], who found 87 species of juveniles in their study of fish assemblages in Caribbean seagrass beds. [22] reported that 42 fish species, 36 species and 27 species were collected from seagrass. [23], reported 37 fish species belonging to 22 families when studying differences in fish assemblage structures between fragmented and continuous seagrass beds in Trang, Southern Thailand. [24], reported 36species of fish from 24 families from spatial patterns in fish herbivory in a temperate Australian seagrass meadow; and [25] noted 35 families. [26] found 65 taxa in 35 families of fish in seagrass beds at Kham Bay, Trang Province, Thailand; [27] identified 70 taxa from diverse species of fish in seagrass beds at Sai Cape, Trang Province, Thailand; and [28] were reported 62 taxa in 35 families of fish in seagrass beds at Ban Pak Klong, Trang Province, Thailand; thier fish diversity were less than in this study. [29] used poison as a sampling technique and found 189 species in 46 families, mainly from Thalassia. [30] found 249 fish species in 62 families from seine net catches; their fish diversity was greater than in this study.

In another study [31] found similar results, as the most abundant fish species were from the families Labridae, Siganidae, Atherinidae, Pomacentridae and Nemipteridae, with variations between the study sites. [23], reported fish species such as Clupeidae, Plotosidae, Leiognathidae, Sillaginidae, Lutjanidae, Lethrinidae and Gerreidae in 


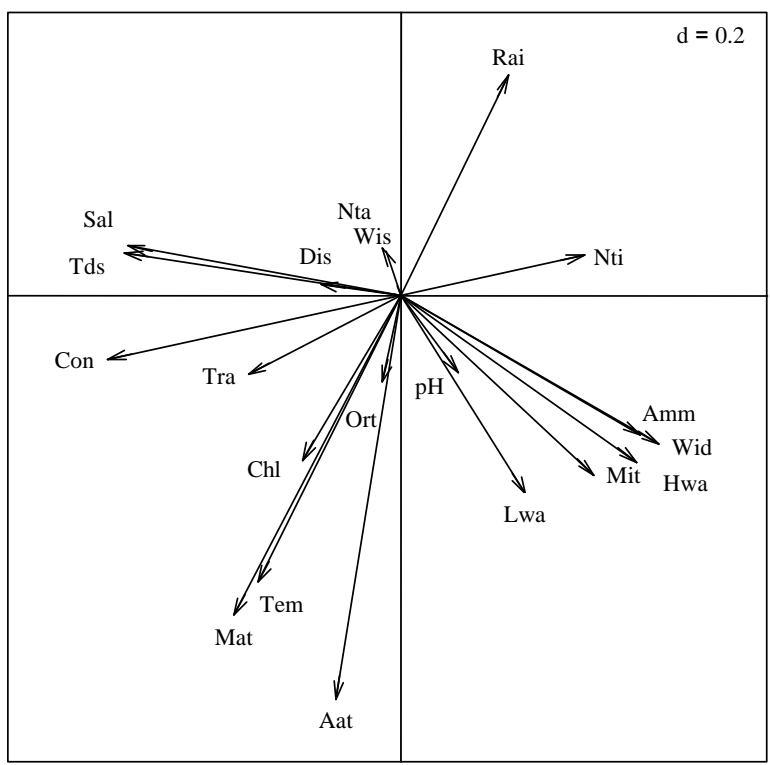

(a)

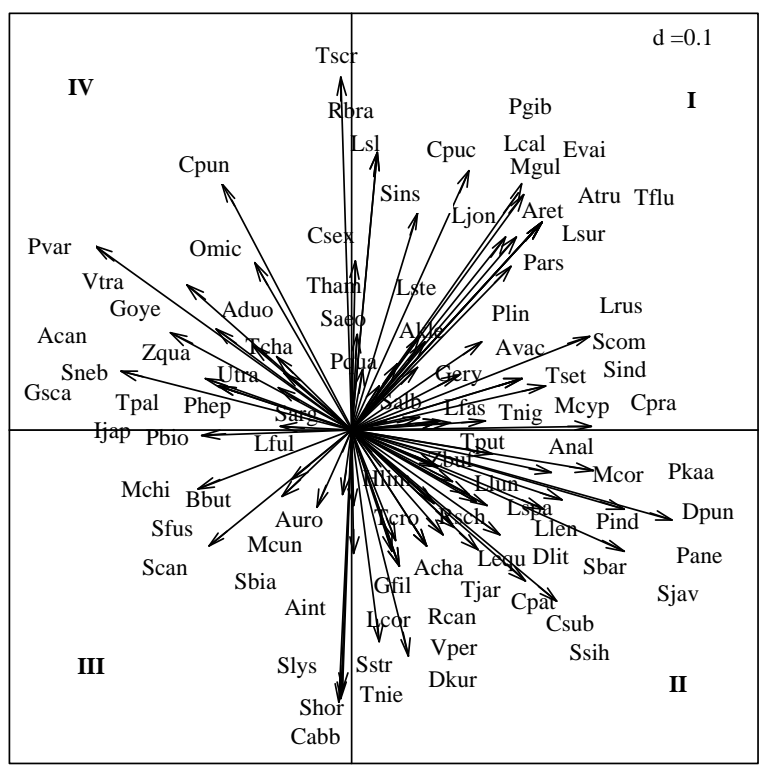

(b)

Cluster Dendrogram

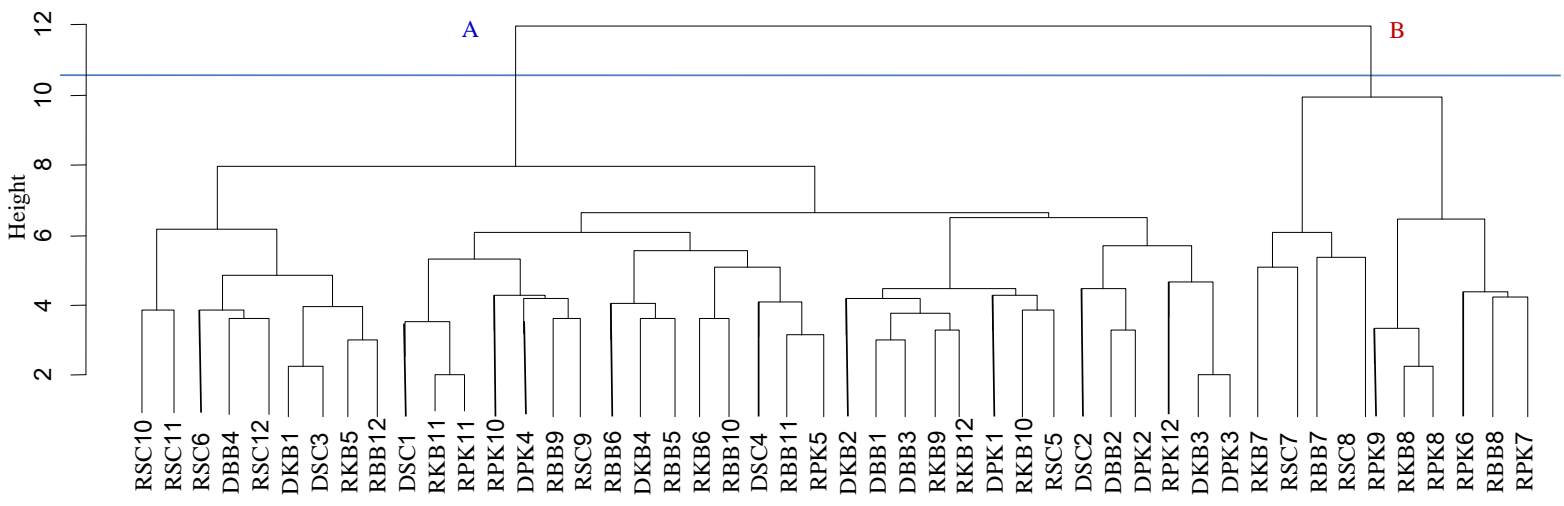

(c)

Cluster dendrogram

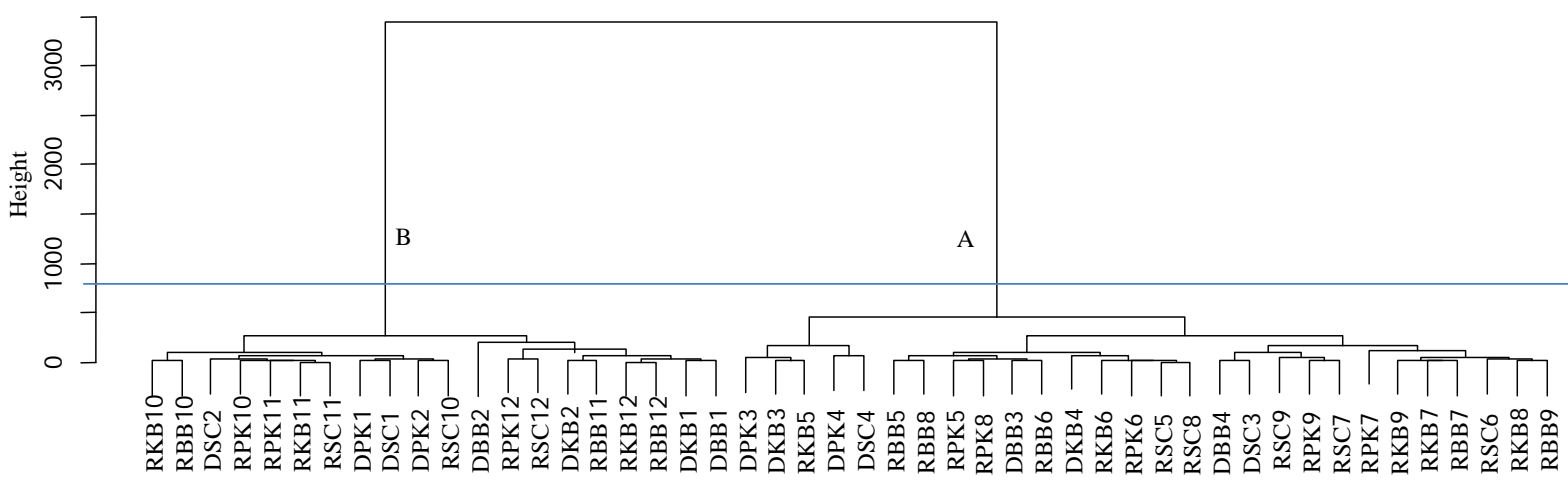

(d)

Figure 5. CCA ordination with species richness related to environmental factors in seagrass meadowns at Sikao Bay, Trang Province, Thailand. (a) Environmental variables loading to CCA axex; (b) PCA analysis of fish assemblage; (c) dendrogram of fish assemblage and; (d) dendrogram of environmental parameters and fish assemblage (RKB = Rain season of Kham Bay, RBB = Rain seasion of Boonkong Bay, RPK = Rain season of Ban Pak Klong, RSC = Rain season of Sai Cape), $(\mathrm{DKB}=$ Dry season of Kham Bay, DBB = Dry seasion of Boonkong Bay, DPK = Dry season of Ban Pak Klong, DSC = Dry season of Sai Cape) and (1-12 = Jan. - Dec.). 
continuous and fragmented beds at the study sites. [32] found that permanent residents were defined by the presence of all life history stages within the habitat. Some common species (Cheilio inermis, Halichoeres argus, Halichoeres chloropterus, Pentapodus trivittatus, Apogon margaritiphorus) were found regularly as both adults and juveniles in the seagrass beds. Other species of reef-associated families that might use adjacent seagrass beds as nurseries were found exclusively as juveniles, such as Chaetodontidae, Haemulidae and Ephippidae.

Another finding was that environmental parameters are important factors for fish distribution patterns. This was proved by CCA, which showed the relation with species richness and indicated patterns in seagrass meadows. The major factors important for fish assemblage were Chl $a$, lowest water level (Lwa) and total dissolved solid (Tds), in relation with season change, fish abundance, fish species and fish species richness. These results are similar with [33] where spatial and seasonal variations of fish assemblages in mangrove creek systems in Zanzibar (Tanzania) were investigated.

\section{Conclusions}

Seagrass meadows provide a permanent and temporary habitat for commercial fishes such as Alepes kleinii, Carangoides praeustus, Megalaspis cordyla, Scomberoides lysan, S. commersonnianus, Decapterus kurroides, Caranx sexfasciatus, Sillago sihama, S. aeolus, Gerres erythrourus, Sardinella albella, Thryssa hamiltonii, Plotosus lineatus, G. oyena and Atherinomorus duodecimalis. The dominant species in our study are A. duodecimalis, Sillago sihama and Pelates quadrilineatus. The highest frequencies of occurrence are $S$. sihama and A. duodecimalis. Fish abundance differs because of varying environmental conditions. Observations of physicochemical water qualities parameters are based on coastal water quality standards.

Overall, 97 fish species and 20 environmental variables are analyzed by CCA, classifying the relationships of fish assemblage structure and environmental parameters into four groups. Two cluster dendrograms summarize the similarity of species richness with environmental parameters, and of environmental parameters with composition in the sampling site throughout the year, respectively. Our study has clearly improved knowledge of fish diversity and the relationship of fish assemblage with environmental parameters in seagrass meadows, and this is important for understanding the functioning and integrity of these ecosystems. Our results can be passed on to local fishermen and responsible stakeholders to encourage them to begin a Thai seagrass meadows conservation program for ecological sustainability in an area with growing tourism.

\section{Acknowledgements}

We are grateful to Rajamangala University of Technology Srivijaya, Faculty of Science and Fisheries Technology, for supporting this study, and to Shell Centennial Education Fund, Shell Companies in Thailand for research funding support. Further thanks to everyone at the Aquatic Resource Research Center (ARC Team) and the Faculty of Fisheries Technology and Aquatic Resources at Maejo University.

\section{References}

[1] Heck, K.L., Hays, G. and Orth, R.J. (2003) Critical Evaluation of the Nursery Role Hypothesis for Seagrass Meadows. Marine Ecology Progress Series, 253, 123-136. http://dx.doi.org/10.3354/meps253123

[2] Jackson, E.L., Rowden, A.A., Attrill, M.J., Bossey, S.J. and Jones, M.B. (2001) The Importance of Seagrass Beds as a Habitat for Fishery Species. Oceanography and Marine Biology, 39, 269-303.

[3] Aaron, A.J., Dahlgren, C.P., Kellison, G.T., Kendall, M.S., Layman, C.A., Ley, J.A., Nagelkerken, I. and Serafy, J.E. (2006) Nursery Functions of Tropical Back-Reef Systems. Marine Ecology Progress Series, 318, 287-301. http://dx.doi.org/10.3354/meps318287

[4] de la Morinière, E.C., Pollux, B.J.A., Nagelkerken, I. and Van der Velde, G. (2002) Post-settlement life cycle migration patterns and habitat preference of coral reef fish that use seagrass and mangrove habitats as nurseries. Estuarine Coastal and Shelf Science, 55:309-321. http://dx.doi.org/10.1006/ecss.2001.0907

[5] Duarte, C.M. (2002) The Future of Seagrass Meadows. Environmental Conservation, 29, 192-206. http://dx.doi.org/10.1017/S0376892902000127

[6] Fortes, M.D. (1990) Seagrasses: A Resource Unknown in the ASEAN Region. ICLARM Education Series, International Centre for Living Aquatic Resource Management, Manila, 46 p.

[7] Parrish, J.D. (1998) Fish Communities of Interacting Shallow-Water Habitats in Tropical Oceanic Regions. Marine Ecology Progress Series, 58, 143-160. http://dx.doi.org/10.3354/meps058143 
[8] Carpenter, K.E. and Niem, V.H. (1999a) FAO Species Identification Guide for Fishery Purposes. The Living Marine Resources of the Western Central Pacific Volume 3: Batoid Fishes, Chimaeras and Bony Fishes Part 1 (Elopidae to Linophrynidae). FAO, Rome, 1397-2068.

[9] Carpenter, K.E. and Niem, V.H. (1999b) FAO Species Identification Guide for Fishery Purposes. The Living Marine Resources of the Western Central Pacific Volume 4: Bony Fishes Part 2 (Mugilidae to Carangidae). FAO, Rome, 20692790 .

[10] Carpenter, K.E. and Niem, V.H. (2001) FAO Species Identification Guide for Fishery Purposes. The Living Marine Resources of the Western Central Pacific Volume 5: Bony Fishes Part 3 (Menidae to Pomacentridae). FAO, Rome, 2791-3380.

[11] Carpenter, K.E. and Niem, V.H., Eds. (2001) FAO Species Identification Guide for Fishery Purposes. The Living Marine Resources of the Western Central Pacific Volume 6: Bony Fishes Part 4 (Labridae to Latimeriidae), Estuarine Crocodiles, Sea Turtles, Sea Snakes and Marine Mammals. FAO, Rome, 3381-4218.

[12] Nelson, J.S. (2006) Fishes of the World. 4th Edition, John Wiley \& Sons, Hoboken, 601 p.

[13] American Public Health Association (APHA), Eton, A.D., Clesceri, L.S., Rice, E.W. and Greenberg, A.E., Eds. (2005) Standard Methods for the Examination of Water and Waste Water. 21st Edition, American Water Work Association, Water Pollution Control Federation, Washington DC, 1368 p.

[14] Information Services, the Climate Bureau of Meteorology (2013) Climate. Thai Meteorological Department, Thailand. http://www.tmd.go.th/services/services.php

[15] Hydrographic Department (2012) Highest and Lowest Water Level of 2012. Hydrographic Department, Royal Thai Navy, Thailand. http://www.hydro.navy.mi.th/services2014.htm

[16] Shannon, C.E. and Weaver, W. (1949) The Mathematical Theory of Communication. University of Illinois, Urbana.

[17] TerBraak, C.J.F. (1986) Canonical Correspondence Analysis: A New Eigenvector Technique for Multivariate Direct Gradient Analysis. Ecology, 67, 1167-1179. http://dx.doi.org/10.2307/1938672

[18] Lek, S. and Guegan, J.F. (2000) Artificial Neural Networks: Application to Ecology and Evolution. Springer Verlag, Berlin.

[19] R Development Core Team (2013) R: A Language and Environment for Statistical Computing. Reference Index Version 2.10, R Foundation for Statistical Computing, Vienna. http://www.r-project.org

[20] Unsworth, R.K.F., Elizabeth, W., David, J.S. and James, J.B. (2007) Diel trophic Structuring of Seagrass Bed Fish Assemblages in the Wakatobi Marine National Park, Indonesia. Estuarine, Coastal and Shelf Science, 72, 81-88. http://dx.doi.org/10.1016/j.ecss.2006.10.006

[21] Dorothie, K., Yolande, B.N., Max, L., David, M. and Claude, B. (2010) Juvenile Fish Assemblages in Caribbean Seagrass Beds: Does Nearby Habitat Matter? Journal of Coastal Research, 26, 1133-1141.

[22] Elbart, J.E., Pauline, M.R. and Rod, M.C. (2007) Fish Assemblages in Seagrass Beds Are Influenced by the Proximity of Mangrove Forests. Marine Biology, 150, 993-1002.

[23] Horinouchi, M., Tongnunui, P., Nanjyo, K., Nakamura, Y., Sano, M. and Ogawa, H. (2009) Differences in Fish Assemblage Structures between Fragmented and Continuous Seagrass Beds in Trang, Southern Thailand. Fisheries, 75, 1409-1416. http://dx.doi.org/10.1007/s12562-009-0166-1

[24] White, K.S., Westera, M.B. and Kendrick, G.A. (2011) Spatial Patterns in Fish Herbivory in a Temperate Australian Seagrass Meadows. Estuarine, Coastal and Shelf Science, 93, 366-374. http://dx.doi.org/10.1016/j.ecss.2011.05.006

[25] Khalaf, M.A., Al-Rousan, S. and Al-Horani, F.A. (2012) Fish Assemblages in Seagrass Habitat along the Jordanian Coast of the Gulf of Aqaba. Natural Science, 4, 517-525. http://dx.doi.org/10.4236/ns.2012.48069

[26] Phinrub, W., Promya, J., Montien-Art, B. and Suvarnaraksha, A. (2013) Fish Diversity and Water Quality in Seagrass Beds at Kham Bay, Trang Province, Thailand. Proceedings of the International Conference on Frontiers of Environment, Energy and Bioscience (ICFEEB 2013), Beijing, 24-25 October 2013, 399-404.

[27] Phinrub, W., Promya, J., Montien-Art, B. and Suvarnaraksha, A. (2013) Fish Diversity in Seagrass Beds at Sai Cape, Trang Province, Thailand. Proceedings of the Sixth International Fisheries Conference with the Theme "Climate Change: Impact on Aquatic Resources and Fisheries, 4 December 2013, Chiang Mai, 7.

[28] Phinrub, W., Promya, J., Montien-Art, B. and Suvarnaraksha, A. (2014) Fish Diversity in Seagrass Beds at Ban Pak Klong, Trang Province, Thailand. Proceedings of the Asian Fish Biodiversity Conference 2014, 12-13 February 2014, Penang, 59.

[29] Vivien, M.L. (1974) Ichtyofaune des herbiers de phanerogames marines du Grand Recif de Tuear (Madagascar). I: Les peuplements et leur distribution ecologique. Tethys, 5, 425-436.

[30] Fiona, R.G. and Mark, W.W. (2002) Diversity of Fishes in Seagrass Beds in the Quirimba Archipelago, Northern Mozambique. Marine \& Freshwater Research, 53, 115-121. http://dx.doi.org/10.1071/MF01125 
[31] Nakamura, Y. and Sano, M. (2004) Comparison between Community Structures of Fishes in Enhalus acoroides and Thalassia hemprichii Dominated Seagrass Beds on Fringing Coral Reefs in the Ryukyu Islands, Japan. Ichthyological Research, 51, 38-45. http://dx.doi.org/10.1007/s10228-003-0191-5

[32] Kuriandewa, T.E., Kiswara, W., Hutomo, M. and Soemodihardjo, S. (2003) The Seagrasses of Indonesia. In: Green, E.P. and Short, F.T., Eds., World Atlas of Seagrasses, University of California Press, Barkeley, 172-182.

[33] Mwandya, A.W., Martin, G., Mathias, H.A., Marcus, C.O., Yunus, D.M. and Ian, B. (2010) Spatial and Seasonal Variations of Fish Assemblages in Mangrove Creek Systems in Zanzibar (Tanzania). Estuarine, Coastal and Shelf Science, 89, 277-286. http://dx.doi.org/10.1016/j.ecss.2010.08.002 